\title{
Characterizing late Quaternary lake-level variability in Lago de Tota, Colombian Andes, with CHIRP seismic stratigraphy
}

\author{
Derek K. Gibson ${ }^{1}$, Broxton W. Bird ${ }^{1}$, Nigel J. Wattrus ${ }^{2}$, Jaime Escobar ${ }^{3,4}$, Maliha Ahmed ${ }^{1}$, \\ Hector Fonseca ${ }^{5}$, Felipe Velasco ${ }^{6}$, Alejandro Fernandez ${ }^{7}$, Pratigya J. Polissar ${ }^{8}$
}

${ }^{1}$ Indiana University-Purdue University Indianapolis, Indianapolis, IN, United States.

${ }^{2}$ University of Minnesota Duluth, Duluth, MN, United States.

${ }^{3}$ Universidad del Norte, Barranquilla, Colombia.

${ }^{4}$ Smithsonian Tropical Research Institute, Panama.

${ }^{5}$ Universidad Pedagógica y Tecnológica de Colombia UPTC, Escuela de Ingeniería Geológica, Sogamoso, Colombia.

${ }^{6}$ Fundación Montecito, Sogamoso, Colombia.

${ }^{7}$ Universidad de los Andes.

${ }^{8}$ Columbia University, Lamont-Doherty Earth Observatory, Earth and Environmental Sciences, Palisades, NY, United States.

This is the author's manuscript of the article published in final edited form as:

Gibson, D. K., Bird, B. W., Wattrus, N. J., Escobar, J., Ahmed, M., Fonseca, H., Velasco, F., Fernandez, A., \& Polissar, P. J. (2019). Characterizing late Quaternary lake-level variability in Lago de Tota, Colombian Andes, with CHIRP seismic stratigraphy. Journal of Paleolimnology, 62(4), 319-335. https://doi.org/10.1007/s10933-019-00089-x 


\section{Abstract}

Geophysical analysis of lacustrine sediment stratigraphy at Lago de Tota (Tota), Boyaca, Colombia provided evidence for significant lake-level fluctuations through the late Quaternary and produced a record that potentially spans the last $60 \mathrm{ka}$. CHIRP data collected in 2015 from this large, high-elevation lake in the Eastern Cordillera of the northern hemisphere Colombian Andes reveal a series of off-lap and on-lap sequences in the upper $\sim 20 \mathrm{~m}$ of the lake's sediment column that indicate large amplitude changes in lake-level. Because ${ }^{14} \mathrm{C}$ dated sediment cores are only available for the upper $3 \mathrm{~m}$ of the sediment column, known Holocene sedimentation rates were extrapolated in order to assign preliminary ages to the off-lap and on-lap sequence boundaries below $3 \mathrm{~m}$ depth. These data suggest that lake-levels at Tota were lower than present during Marine Isotope Stage (MIS) 4 between 60 and 57 ka, relatively high during MIS 3 between 57 and $29 \mathrm{ka}$, fell to their lowest levels during MIS 2 between 29 and $14 \mathrm{ka}$, and gradually rose to the modern high-stand through a series of transgressions during MIS 1 and the Holocene from $\sim 14$ ka to the present. These fluctuations are broadly consistent with trends observed in other lake-level reconstructions from the northern (in phase) and southern (out of phase) hemisphere Andes, possibly supporting the idea that millennial-to-orbital-scale South American hydroclimate variability is linked to shifts in the mean latitude of the Intertropical Convergence Zone (ITCZ) due to the influence of insolation- and ocean circulation-driven hemispheric temperature gradients during glacial/stadial and interglacial/interstadial events. Although additional geochronological data will be needed to better resolve the timing of the Tota lake-level changes and their relationships with other records, these preliminary results from Tota, as well as the presence of a thick ( $>300 \mathrm{~m})$ sedimentary archive, indicate that this site has 
significant potential to produce high-resolution, quantitative, paleo-hydroclimate data spanning much of the last 1 million years. Because geophysical surveys and long paleoclimate records from northern hemisphere South America are exceedingly rare, these data provide critical insight into regional hydroclimate trends through the Late Quaternary. Additional work, such as the collection of sediment cores spanning the depth interval represented in the CHIRP data, is required, however, in order to place firmer chronological constraints on the hypothesized timing of lake-level fluctuations at Tota and to investigate their paleo-hydroclimatic implications.

\section{Introduction}

The South American monsoon system (SAMS) is the largest monsoon system in the Southern Hemisphere and delivers $>50 \%$ of the annual precipitation for tropical and subtropical South America (Vuille and Werner 2005; Garreaud et al. 2009). In the tropical Andes, SAMS precipitation is stored in lakes, wetlands, and glaciers. These natural reservoirs provide critical freshwater resources relied on throughout the year by ecological, domestic, and industrial systems, especially those along the hyper-arid Pacific coast (Viviroli et al. 2007; Flantua et al. 2016). As a result, there is considerable interest in how the SAMS will respond to continued increases in global temperatures. Essential to predictive modeling of the SAMS is understanding the natural range of hydrologic variability in response to abrupt and large magnitude changes in global climatic boundary conditions. Empirical and quantitative paleoclimate records of past hydrologic variability that can be directly linked to the SAMS are key components of this effort. Paleoclimate records that specifically span the late Quaternary are especially important because the large changes in climatic boundary conditions that occurred during the transitions into and 
out of glacial and inter-glacial periods $\left(+/-6\right.$ to $\left.8^{\circ} \mathrm{C}\right)($ Bintanja et al. 2005) are of similar magnitude to those proposed under the upper end estimates of emissions scenarios by the IPCC $\left(+8^{\circ} \mathrm{C}\right)$

Considerable research has been conducted in recent decades to investigate fluctuations in the intensity of the SAMS during the late Quaternary (Haug et al. 2001; Wang et al 2006; Cruz et al 2009). On orbital timescales, it is suggested that monsoon intensity tracked precessional insolation forcing of the Intertropical Convergence Zone (ICTZ) such that peak monsoon intensity occurred in the hemisphere with maximum summer insolation (Grimm 2003; MollierVogel 2013). For example, oxygen isotope ratios $\left(\delta^{18} \mathrm{O}\right)$ in speleothems from Botuverá Cave in southern Brazil provides a $90 \mathrm{ka}(\mathrm{ka}=$ kilo annum before present; present $=1950 \mathrm{AD})$ record of precipitation $\delta^{18} \mathrm{O}$ that closely follows precessional insolation, indicating a weakened SAMS during Marine Isotope Stage (MIS) 3a (38 to $25 \mathrm{ka}$ ) and a strengthened SAMS during MIS 2 (Wang et al. 2007). Consistent with hemispheric antiphasing that would result from ITCZ modulation of tropical monsoons, opposite hydroclimate trends are apparent in a northern hemisphere South American lake-level record from Lake Fúquene (van der Hammen 1974; Bogota-a et al. 2011). This site shows water balance trends of moderately high, but variable, lake-levels during MIS 3a, low levels during the LGM (25 to $19 \mathrm{ka}$ ), and high levels during the Holocene.

ITCZ variability has similarly been invoked to explain millennial tropical hydroclimate variability, with changes in the position of the ITCZ driven by hemispheric temperature gradients resulting in part from North Atlantic ocean circulation and sea surface temperature (SST) variability (Mosblech et al. 2012). Northern hemisphere cooling in response to reduced Atlantic Meridional Overturning Circulation (AMOC), such as during Heinrich Events 1 and 2 (H1; 19- 
$17.5 \mathrm{ka}$ and $\mathrm{H} 2$; 24-22 ka) and the Younger Dryas (YD; 12.9-11.7 ka) for example, is suggested to have induced a southward displacement of the ITCZ that enhanced precipitation over southern hemisphere South America (Baker et al. 2001b; Haug et al. 2001), while decreasing it in the northern hemisphere (Peterson et al 2000). This process is consistent with sub-orbital and millennial-scale hydroclimate antiphasing identified in paleoclimate reconstructions from the Cariaco Basin in the northern hemisphere and Botuverá Cave to the south. In the Cariaco Basin, a decrease in riverine discharge during the YD has been interpreted to indicate a reduction of precipitation during that time (Haug et al. 2001). Conversely, speleothem $\delta^{18} \mathrm{O}$ values from Botuverá during this same timespan were low, indicating increased precipitation (Cruz Jr et al. 2005; Wang et al. 2006).

While these studies provide insight into SAMS dynamics, the majority of orbital- and millennial-scale South American hydroclimate records are from the southern hemisphere. As a result, questions remain regarding the spatiotemporal nature of SAMS hydroclimate responses in the northern hemisphere Andes to late Quaternary changes in climatic boundary conditions and their relationship with southern hemisphere climatic events. For instance, while hydrologic responses to the late Quaternary MIS stages have been investigated in the southern hemisphere with speleothem, ice core, lacustrine, and other natural archives, similar studies that focus on the northern hemisphere hydroclimate during these times are few. In order to better understand the nature of late Quaternary hydroclimatic variability in northern hemisphere South America, it is necessary to develop records that preserve northern hemisphere hydrologic responses to major orbital and millennial scale climatic events, such as those which occurred during glacial and interglacial periods, Heinrich Events, and other major climate perturbations. 
Here, we present a geophysical investigation of the sediment stratigraphy at Lago de Tota (Tota) to investigate its suitability as a northern hemisphere study site for Pleistocene and Holocene South American paleoclimate reconstructions. We identify orbital-to-millennial-scale lake-level and volume variability associated with high- and low-lake-stand system tracts preserved in the sediment stratigraphy at Tota, providing insight into the long-term balance between precipitation and evaporation $(\mathrm{P} / \mathrm{E})$ at Tota that potentially spans the last $60 \mathrm{ka}$.

Site Description

Tota is a large, high-altitude (3015 m above sea-level; asl) lake located in the Eastern Cordillera of the Colombian Andes $\left(5.54^{\circ} \mathrm{N}, 72.92^{\circ} \mathrm{W}\right)$ (Fig. 1). It is the largest high-altitude water body in Colombia with a surface area of $55.1 \mathrm{~km}^{2}$, an average depth of $34 \mathrm{~m}$, a maximum measured depth of $62 \mathrm{~m}$, and a volume of $1.94 \times 10^{9} \mathrm{~m}^{3}$. The watershed surrounding Tota exceeds $200 \mathrm{~km}^{2}$, with an elevation range of $\sim 3015-3800 \mathrm{~m}$ asl and is located near the divide between the Orinoco and Magdalena River catchments. Although outflow from the lake during high-flow events contributes to the headwaters of the Upia River, Tota is a generally closed system in that the principle driver of lake surface area and volume is the balance between local precipitation and evaporation; i.e, outflow and loss to groundwater are negligible compared evaporative loss over the millennial timescales presented here. Locally, more than 400,000 people rely on Tota as a reservoir for drinking water, agriculture, and industry.

Structure, lithology, and bathymetry 
Tota is one of 17 highland tectonic basins in the Eastern Cordillera of the Colombian Andes that were formed through the deformation of pre-foreland and back-arc megasequences during Tertiary uplift and folding across the northern Andes (Eidt 1968; Fonseca and Reyes 2016). As a result, the local geology is structurally complex; characterized by west-east trending transform and reverse faults along the eastern shore of the lake. Subsurface synclines and anticlines throughout the watershed create additional structural complexities. Large sedimentary aprons comprised of Quaternary alluvium, fluvial deposits, and lacustrine deposits cover most of the bedrock to the east of the lake along the eastern shore of Aquitania Bay, while the northeast section of the basin is characterized by well-exposed outcrops of siliciclastic sedimentary rock (Fonseca and Reyes 2016).

The bathymetry of Tota is characterized by a flat profundal zone that shallows gradually to the east and south and very sharply along the structurally-controlled western and northern shores (Fig. 2a). Peninsulas and islands created by subsurface anticlines extend into the eastern side of the lake from the north and south, separating Aquitania Bay from the main body of the lake.

\section{Local climate}

The drainage basin surrounding Tota is dominated by farmland at the lower altitudes and páramo biomes at higher altitudes, reaching elevations exceeding $3800 \mathrm{~m}$ asl (Fonseca and Reyes 2016). Despite its tropical latitude, the high elevation results in generally cool conditions, with a diurnal temperature range of up to $20^{\circ} \mathrm{C}$ (van der Hammen and Hooghiemstra 2000). At present, the 
prevailing wind direction trends from the southeast to the northwest during the warm season and from the northeast to the southwest during the cool season (Gelbrecht et al. 2017).

Over interannual and decadal timescales, ocean-atmosphere interactions affect moisture delivery associated with the SAMS, most notably the El Nino Southern Oscillation (ENSO) and the Pacific Decadal Oscillation (PDO) (Garreaud et al. 2009; Cañón Barriga and Valdes 2011; Poveda et al. 2011). Both mechanisms display harmonic characteristics; with positive and negative phases respectively associated with high and low SST anomalies in the eastern and central Pacific Ocean that produce changes in atmospheric subsidence and wind direction, affecting convection in tropical South America. During positive ENSO and PDO modes when SSTs in the eastern equatorial Pacific are anomalously warm, Tota experiences dry conditions, while negative ENSO and PDO modes result in cooler SSTs and relative increases in precipitation at the lake (Cañón Barriga and Valdes 2011). Shifts between modern ENSOpositive and ENSO-negative phases occur every 2 to 7 years, within the lower-frequency (15-30 year) PDO oscillations (Mantua and Hare 2002).

On millennial and orbital timescales, the influence of precessional forcing and North Atlantic teleconnections on the mean latitude of the ITCZ have been proposed to be the greatest contributor to SAMS strength and the spatial distribution of South American annual precipitation (Poveda and Mesa 1997; Pahnke et al. 2007).

\section{Materials and methods}

CHIRP data collection and processing 
The uppermost portion of the sediment column at Tota, including the sediment-water interface, was imaged using a swept-frequency Edgetech 3100P Compressed High Intensity Radiative Pulse (CHIRP) sub-bottom profiler coupled with an Edgetech SB-424 Towfish, which was towed across the lake surface in a grid of intersecting transects totaling $\sim 63 \mathrm{~km}$ (Fig. 2b). Signal penetration is dependent on the output signal's frequency and the character of the sediment below the modern sediment-water interface, with greater penetration in fine-grained muds and clays. In order to convert time surfaces to depth, the speed of sound was assumed to be $1500 \mathrm{~m} \mathrm{~s}^{-}$

${ }^{1}$ through the water, increasing to $1550 \mathrm{~m} \mathrm{~s}^{-1}$ through the water-saturated and loosely consolidated shallow subsurface sediments (Hamilton 1979). The CHIRP signal (10 ms, swept from $400 \mathrm{~Hz}$ to $16 \mathrm{kHz}$ ) provided seismic data that represented the water column and the top $\sim 20$ $\mathrm{m}$ of the sedimentary archive. Below this depth, which corresponded with a two-way travel time (TWTT) of approximately 0.07 seconds, the signal-to-noise ratio of the seismic data became too low for data interpretation.

All processing of the seismic data, including deconvolution, filtering, reflector tracing, and interpretation, were conducted using the IHS Kingdom software suite.

\section{CHIRP reflection transect selection}

Near-surface gas accumulations in the northern lake basin severely attenuated seismic signals and obscured deeper reflectors; however, CHIRP data collected in the southwestern and southeastern basins were easily detectable and traceable. Data from these areas: (1) were not obscured by near-surface gas pockets; (2) showed no offset from neo-tectonics, which indicates that lake-level changes reflected in the CHIRP data are truly due to lake volume changes, rather 
than to displacement of the water column due to faulting; (3) displayed on-lap and off-lap lithostratigraphic sequences characteristic of nearshore margins in response to lake-level changes; and (4) were traceable across the lake basin such that correlation between the southwestern and southeastern basin was possible. For these reasons, we chose to focus on CHIRP transects from the southern basin of Tota for a detailed analysis of past lake-level changes. In addition to the abovementioned benefits, the bathymetry across the southern basin changes more gradually than in other sections of the lake, causing lake-level changes to impart a greater influence on shoreline migration, which is preserved in the lithostratigraphy and reflected in the seismic data.

Age control

Three surface cores and three longer Livingstone cores collected in 2013 and 2015 were dated using radiocarbon accelerated mass spectrometry $\left({ }^{14} \mathrm{C}\right.$ AMS $)$. Fourteen ${ }^{14} \mathrm{C}$ dates were collected and calibrated using standard CALIB and CALIBOMB methods (Stuvier and Reimer 1993; Reimer et al. 2004). Although not long enough to capture the entire $\sim 20 \mathrm{~m}$ represented by the CHIRP data, age control for the two uppermost stratigraphic units (upper $3 \mathrm{~m}$ ) was provided by dates from these cores (Fig. 3, Table 1).

Mud deposition boundary depth

The mud deposition boundary (MDB) depth is the depth at which the high-energy erosive nearshore environment (characterized by sand) transitions into lower energy environments where 
fine-grained sediments (silts and clays) are deposited. One method for calculating the mud deposition boundary uses the equation $\mathrm{MDB}=2.685 \mathrm{E}^{0.305}$ (Rowan et al. 1992) where $\mathrm{E}$ is lake exposure, defined as the area of the lake in $\mathrm{km}^{2}$, which has been demonstrated to serve as a reliable proxy for average wave height when calculating the upper limit of the MDB. Applying the above equation to the surface area of Tota $\left(55.1 \mathrm{~km}^{2}\right)$ provides a calculated MDB of $9.12 \mathrm{~m}$. However, fine grained sediment deposition does not occur on the southwestern shores of Tota until a depth of approximately $30 \mathrm{~m}$. This discrepancy may result from a combination of sediment redistribution via nearshore currents and the steep slope of the western shoreline, on which it would be difficult to accumulate sediment. Rowan et al (1992) calculated the effects of shoreline gradient on sediment deposition and found that the slope of the shoreline reduces sediment stability and increases wave interaction with the nearshore lake bottom such that finegrained lacustrine sediments are rarely found on slope gradients $>10 \%$. However, by consistently using the mud deposition boundary reflected in the CHIRP data, the described changes in paleoshoreline and lake-level remain semi-quantitative; with the assumption that the shoreline gradient, wind fields, and other water-sediment dynamics have been largely consistent throughout the temporal range of this study.

\section{Results}

Age Control

Three $\sim 3 \mathrm{~m}$ Livingstone cores and three shorter surface cores that were collected near the southwestern shore of Tota and across Aquitania Bay display a down-core transition from highly-organic peaty sediments to low-organic clay-rich sediments. Radiocarbon dates from the 
organic-clay transition show that it occurred at $\sim 10 \mathrm{ka}$, indicating that the lower clay unit is of Late Glacial origin and that the organic rich sediments were deposited during the Holocene (Fig. 3, Table 1). The Holocene section is represented by $3 \mathrm{~m}$ of accumulation, suggesting an average sedimentation rate of $\sim 1 \mathrm{~m}$ per 3000 years. The organic-clay boundary is traceable in the CHIRP data across the lake basin and is represented by the seismic sequence (SS) 9 to SS 8 transition (Fig. 5b), providing chronological constraints on the uppermost section of the seismic data. Ages of the subsequent stratigraphic boundaries were estimated by extrapolating the Holocene age model and compared with other South American climate records to evaluate error.

The three $\sim 40 \mathrm{~cm}$ surface cores collected along a transect from the southwestern shore to the mouth of Aquitania Bay provided additional material for radiometric dating. Based on ${ }^{14} \mathrm{C}$ data, these cores span the last $\sim 1200$ years, which equates to 30 years per $\mathrm{cm}$, or 3000 years per $\mathrm{m}$, consistent with the ${ }^{14} \mathrm{C}$-dated Livingstone cores (Table 1). The similar sedimentation between the Livingstone and surface cores suggest more or less consistent Holocene sedimentation rates of approximately 3000 years per $\mathrm{m}$. Although it is acknowledged that sedimentation rates likely varied to some extent during different past climatic parameters, we used a sedimentation rate of 1 $\mathrm{m}$ per 3000 years to approximate the age of transgressive and regressive sequences apparent in the CHIRP data below the SS8-SS9 boundary. The age model approach taken here is admittedly inadequate and additional dates are needed to constrain the ages of seismic units. In the absence of longer, well-dated sediment cores, our approach permits a first approximation to be made of age-depth relationships that allows for hypotheses to be generated that can later be tested with additional data and chronological control.

Lake-level reconstruction 
Analysis of the CHIRP data from the southern basin of Tota revealed 9 seismic units that were consistent in terms of thickness and facies between the southwestern and southeastern shore of the lake (Fig. 4). These units were designated SS 1 through 9 from oldest to youngest (Fig. 5d). Although SS1 is the deepest seismic unit described in our study, air gun seismic reflection data indicate that the complete sediment package at Tota exceeds $350 \mathrm{~m}$. The relatively higher frequency and lower energy of the CHIRP system, however, precludes signal penetration beyond the upper tens of meters, which is why we focus here on the uppermost section of the sediment column. All sequences are bounded by onlapping reflections or top-lap surfaces and therefore represent unique periods of depositional conditions (Fig. 5). From the observed sequences, we were able to reconstruct a continuous semi-quantitative history of the lake-level changes at Tota, which, by extrapolation, we interpret to span approximately the last 60,000 years (Table 2). The magnitude of lake-level variability reflected by the CHIRP data was determined by comparing the relative magnitudes of transgressions and regressions of the nearshore boundary of finegrained lacustrine muds that occur during each sequence. The boundaries and thicknesses of the identified depositional sequences at Tota are presented in Table 2.

MDB fluctuations

Accompanying lake-level and volume fluctuations at Tota were horizontal changes in the location of the lake's MDB (Table 2). By comparing the horizontal offset between the nearshore terminations of adjacent seismic units near the southwestern shoreline, we estimated the distance each sequence transgressed or regressed in relation to the modern MDB. It should be noted that 
this proxy of shoreline evolution is only true for the southwestern shore, because local bathymetry is a key factor in determining the magnitude to which a given lake-level shift will affect shoreline position. As the bathymetry of Tota is irregular, the same magnitude of shoreline change would not occur uniformly around the lake. However, shoreline changes are more directly related to lake-area changes in basins such as Tota where the bathymetry is evolving due to sediment accumulation. Lake area is a primary determinant of water loss in closed-basin lakes and is therefore a more direct record of climate-related lake fluctuations than lake depth or volume. Therefore, the relative magnitude of shoreline migration (as indicated by the magnitude of MDB transgressions and regressions) along the southwestern shoreline provide an additional indicator of the magnitude of hydrologic variability experienced by Tota that complements the vertical and volumetric water column changes represented by each depositional sequence. The magnitude and relative timing of shoreline migration were as follows (Table 2):

SS1: The MDB during the SS1 sequence was $\sim 120 \mathrm{~m}$ offshore from the current MDB.

SS2: As lake-level rose during the SS1 to SS2 transgression, the MDB transgressed $45 \mathrm{~m}$ inland $75 \mathrm{~m}$ offshore from the modern position.

SS3: The MDB transgressed an additional $15 \mathrm{~m}$ during the SS2-SS3 transgression, migrating within $60 \mathrm{~m}$ of the modern position.

SS4: During the SS3-SS4 regression, the MDB receded by $85 \mathrm{~m}$, to $145 \mathrm{~m}$ offshore from the modern position.

SS5: During this period, the lowest lake-level recorded in our data, the MDB receded by an additional $105 \mathrm{~m} ; 250 \mathrm{~m}$ from the modern. 
SS6: The MDB migrated $205 \mathrm{~m}$ inland to within $40 \mathrm{~m}$ of the modern position during this sequence.

SS7: The MDB receded $75 \mathrm{~m}$ during the SS6-SS7 regression, which moved the MDB to $115 \mathrm{~m}$ offshore from the modern.

SS8: The MDB transgressed $30 \mathrm{~m}$ during the deposition of SS8, to $85 \mathrm{~m}$ offshore from the modern.

SS9: Lake-level continued to rise during the deposition of SS9 and the MDB transgressed an additional $80 \mathrm{~m}$, as the shoreline reached its modern position.

\section{Reflector morphology}

Two main morphological facies are visible in the CHIRP data. The most common sequence truncations are represented by onlap and offlap structures. These boundaries occur between sequences 1-2 (onlap), 3-4 (offlap), 4-5 (offlap), 6-7 (offlap), 7-8 (onlap), and 8-9 (onlap). These sequence truncations are identifiable by their diagnostic "pinch-out" morphology. Sequences SS3 and SS6 do not have this characteristic, appearing lobate in the CHIRP data instead, with nearshore truncations slightly thicker than the rest of the unit. The CHIRP data also display two primary types of internal reflectivity, with some sequences appearing nearly transparent (e.g., SS9) while others (e.g., SS8) are much more opaque (Fig. 5). Sediment cores that span the SS9SS8 transition suggest that these differences are due to changes in sediment composition between sequences (Fig. 5b), though longer cores would be needed to confirm this. 


\section{Discussion}

Limitations

Highly specialized coring equipment is required to collect long sediment cores from Tota because of the extreme water depths and density of the clay units below the organic Holocene deposits in the near shore environment. Due to these limitations, age control from sediment cores was only available for the upper $3 \mathrm{~m}$ of sediments. Age-depth relationships beyond this depth are admittedly highly speculative and based on the extrapolation of sedimentation observed within the upper $3 \mathrm{~m}$. Despite this uncertainty, it has been shown that it is not uncommon for lacustrine systems to retain broadly linear sedimentation rates across climatic boundaries due to the alternation of organic and clastic deposition - i.e., as organic deposition declines, clastic input increases and vice versa (Hodell et al. 2008; Stansell et al. 2010). While it is acknowledged that additional age control is needed to definitively constrain age-depth relationships, the similarities between the lake-level record at Tota, other South American climate records, and the timing and magnitude of marine isotope stages during the last $\sim 60,000$ years suggests linkages between global temperatures, high-latitude ice volume, SSTs, and tropical hydroclimate variability during the late Quaternary.

Additional uncertainty is presented by the lobate characteristics of SS3 and SS6. This morphology is likely due to mass sedimentation from the adjacent, steep littoral zone. Because this obscures the original sequence boundary of these units at the MDB, it was necessary to 
estimate the original nearshore boundaries of these two depositional sequences. This limits absolute precision regarding the magnitude of MDB migration and lake-level change during these sequences, but the general trends of transgression and regression (and thus contemporary hydroclimate trends) are still identifiable. Changing wind-wave dynamics and sediment compaction over time could also affect the offshore distance of the MDB and the depth to individual reflectors to some extent, so without long sediment cores the inferred changes in lake level must be treated as apparent, rather than definitive. Nonetheless, specific hypotheses can be, and are, drawn from the available data that provide a framework for further investigations and underscore the potential for future data from Tota to address significant outstanding paleoclimate questions about natural variability in the SAMS and its response to large-scale and abrupt changes in global climatic boundary conditions.

Evidence for late Quaternary lake-level variability at Tota

Although there is evidence of past tectonic activity at Tota (Fig. 7), there is no indication in the seismic data of faulting significant enough to account for the $\sim 20 \mathrm{~m}$ of lake-level variability observed in this study. Furthermore, the seismic data show both increases and decreases in lakelevel, as opposed to the unidirectional rise that would be expected if the variability was tectonically-driven within the compressional structural regime of the study site (Fonseca and Reyes 2016). Therefore, the lake-levels described below are attributed to lake volume changes related to $\mathrm{P} / \mathrm{E}$ balance, rather than displacement of water due to faulting or changes in the elevation of the outlet. 
The CHIRP reflection data show an alternating sequence of onlapping and offlapping geometries that are suggestive of significant lake-level variability at Tota during the recent geologic past. Extrapolating Holocene sedimentation rates based on ${ }^{14} \mathrm{C}$ ages from six sediment cores $\left(3000 \mathrm{yr} \mathrm{m}^{-1}\right)$ suggests that the $\sim 20 \mathrm{~m}$ penetration of the CHIRP data may represent up to 60,000 years of sediment accumulation, with the deepest stratigraphic unit SS1 corresponding with the end of MIS 4 (Vandergoes et al. 2005).

Our geophysical lake-level reconstruction and preliminary age model suggest that climate-hydroclimate linkages played an important role in determining the water balance at Tota during the period of time represented by the CHIRP data. Specifically, lake-level at Tota was generally lower than modern during the deposition of the oldest sequence in the CHIRP data (SS1, $\sim 60,000$ years). The lake-level then rose during two successive transgressive sequences between $\sim 60$ and $\sim 27 \mathrm{ka}$ (SS2 and SS3). This corresponded to a $\sim 60 \mathrm{~m}$ transgression of the MDB as surface area expanded and lake-level rose. The timing of this increase in lake-level is consistent with increases in northern hemisphere precipitation that occurred in response to reductions in high latitude ice volume and the subsequent northward ITCZ migration during MIS 3 (Liu et al. 2010). Following these transgressive events, two regressive sequences between $\sim 27$ and $\sim 23 \mathrm{ka}$ (SS4 and SS5) resulted in a $\sim 250 \mathrm{~m}$ regression of the MDB and a substantial reduction in lake volume and surface area. The timing of these significant low-stands appears to be consistent with a southward displacement of the ITCZ in response to the large-scale Northern Hemisphere glaciations during MIS 2 and the LGM. Following the LGM low-stand, lake volume increased over a $\sim 7000$-year period between $\sim 23$ and 16 ka (SS6), during which the MDB advanced to within $50 \mathrm{~m}$ of its present-day position. This coincides with the onset of rapid postLGM warming, high latitude ice loss, and a northerly migration of the ITCZ (Yokoyama et al. 
2001). The MDB at Tota subsequently regressed $75 \mathrm{~m}$ as lake volume was reduced between $\sim 16$ and $13 \mathrm{ka}$. The timing of this event suggests that precipitation may have been reduced in response to high latitude cooling during H1, which resulted in hydroclimate-ITCZ relationships similar to those during stadials (McGee et al. 2014). Between 11 and $9 \mathrm{ka}$ (SS8), and 9 ka to the present (SS9), lake volume increased, reaching its present-day capacity. The timing of the final transgressive sequence, during which Tota reached its modern volume and lake-level $(10,000 \mathrm{ka})$ (Fig 5), is constrained by ${ }^{14} \mathrm{C}$ dates and is consistent with the warmer conditions of MIS 1 and the Holocene interglacial, during which northern hemisphere ice sheets receded to their present positions, and the ITCZ migrated to the north.

On the millennial timescales represented by the CHIRP data presented here, variations in the latitude of the ITCZ are hypothesized to be the primary driver of tropical hydroclimate variability at Lago de Tota. For South America in general, the current paradigm is that latitudinal changes in the mean position of the ITCZ during stadials (southerly mean ITCZ position) and interstadials (northerly mean ITCZ position) controlled the distribution of moisture, resulting in hemispherically antiphased hydroclimate signals. Mechanistically, insolation changes during stadials (e.g., MIS 4 \& 2) are suggested to have increased Northern Hemisphere ice cover, thereby contributing to atmospheric cooling and drying throughout the northern hemisphere (Broccoli et al. 2006; Schneider et al. 2014). In response, increased evaporation from cool, dry winds reduced SST, further lowering temperatures across the northern hemisphere and enhancing hemispheric SST gradients (e.g., cool northern, warm southern hemisphere). As a result, the thermal equator and ITCZ were displaced southward toward the warmer southern hemisphere, increasing precipitation at southern tropical sites and decreasing it in the north (Chiang and Bitz 2005). These teleconnections are likely the primary drivers of the low lake-levels observed in 
SS4, SS5, and SS7 at Tota. During interstadial/interglacial periods (e.g., MIS 3 \& MIS 1, respectively), warmer average global temperatures and reduced northern hemisphere ice cover caused a reversal of the abovementioned feedbacks and a subsequent northern displacement of the thermal equator and ITCZ, resulting in increased precipitation in the northern hemisphere tropics and reduced precipitation in the southern hemisphere tropics (as shown in SS2, SS3, SS6, SS8, and SS9) (Ivanochko et al. 2005).

Regional Interhemispheric Comparisons and Mechanisms

The lake-level history of Tota is broadly consistent with a lake-level reconstruction from nearby

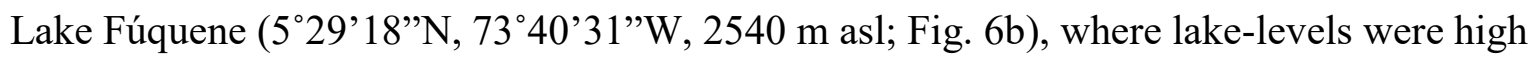
during the Holocene and MIS 3 and low during the LGM (MIS 2). Lake-levels at Fúquene and Tota also similarly show low-stands during the Younger Dryas cooling event and Heinrich events 1, 2 and 3 (Fig. 6b, c) (van der Hammen 1974; Bogota-a et al. 2011). This in-phase, crosswatershed correlation strengthens the hypotheses that 1) the Tota chronology is broadly accurate, 2) the timing of hydroclimate trends in the Colombian Andes may be regionally coherent, and 3) regional hydroclimate is sensitive to changes in global climate boundary conditions related to ITCZ variability. While these hypotheses must be tested with an improved geochronology from longer sediment cores from Tota, the relationship between the lake-levels at Tota and other South American climate records provides support to the current age model extrapolation.

Further comparisons between Tota and Fúquene and southern hemisphere lake-level reconstructions from Salar de Uyuni in Bolivia and Lake Titicaca in Peru show hemispherically opposing trends (Fig. 6, d, e). For example, Salar de Uyuni and Titicaca exhibited high lake- 
levels during MIS 2 and low levels during MIS 1 (Baker et al. 2001a; Fritz et al. 2004), whereas Tota and Fúquene were low during MIS 2 and high during MIS 1. These records are also antiphased over sub-orbital timescales, such as during the Younger Dryas and Heinrich events.

In addition to lake-level records, several non-lacustrine climate records support hemispheric hydroclimate antiphasing. For example, a 120 ka oxygen isotope $\left(\delta^{18} \mathrm{O}\right)$ record produced from speleothem calcite collected from Botuvera' Cave in southern Brazil display higher $\delta^{18} \mathrm{O}$ during MIS 2, the Younger Dryas, and during Heinrich events, possibly suggesting warmer and wetter conditions, and lower $\delta^{18} \mathrm{O}$ during MIS 1 and most of MIS 3 (cooler/drier) (Figure 6f) (Cruz Jr et al. 2007; Wang et al. 2007). In the northern hemisphere, ice cores collected by the Northern Greenland Ice Core Project (NGRIP) display opposite trends, with generally low isotopic values during MIS 2, the Younger Dryas, and during Heinrich events (Fig. 6a) (Members 2004).

Geophysical lake-level reconstruction and analyses of ostracod $\delta^{18} \mathrm{O}$ and $\delta^{13} \mathrm{C}$ from Lake Petén Itzá in Northern Guatemala indicate high lake-levels during MIS 1 and low levels during H1 similar to the northern hemisphere records mentioned above (Anselmetti et al. 2006; Hodell et al. 2008; Mueller et al. 2010; Escobar et al. 2012). However, Lake Petén Itzá experienced relatively higher lake-levels during MIS 2 and experienced its lowest low-stand during H1, while lake-levels at Tota and Fúquene were at their lowest during MIS 2. A number of mechanisms (Escobar et al. 2012) have been proposed to explain this apparent discrepancy between the northern hemisphere records during MIS 2, including: (1) a splitting of the jet stream into a dry northern branch and wet southern branch during MIS 2, which would have delivered precipitation to the western United States and Central America, while sites near the equator (e.g., Tota and Fúquene) would have been located far enough south to avoid any precipitation changes 
due to the influence of the southern branch; (2) transport of moisture from the high latitudes of the northern Pacific Ocean, which could have delivered precipitation to Lake Petén Itzá, but would have been less likely to penetrate south into the interior of the Colombian Andes; and (3) increased winter precipitation at Petén Itzá during MIS 2, which could be a local climatic pattern that did not manifest at other northern hemisphere South American sites. Each of these possible mechanisms would result in wetter conditions at Petén Itzá than at Tota or Fúquene during MIS 2, while the southern hemisphere sites continued to receive increased precipitation due to the southerly ITCZ.

Tota CHIRP as a basis for future work

The antiphased relationship between the northern and southern hemisphere Andean hydroclimate records on millennial timescales is consistent with ITCZ forcing of north-south tropical climate variability in response to stadial/interstadial climate boundary conditions. The resolution of current lake-level reconstructions from the northern hemisphere Andes that span beyond the Holocene, however, is too low, and in the case of Tota, too poorly dated to more rigorously investigate the timing and nature of interhemispheric relationships. In order to better investigate and test hypotheses regarding the spatiotemporal patterns and mechanisms of interhemispheric late Quaternary South American hydroclimate, paleoclimate records with higher-resolution and better age control are needed from the northern hemisphere Andes. Although low-resolution, the Tota CHRIP data indicate that it is an ideal lake site from which to develop such a record. Specifically, with long sediment cores from Tota spanning the interval represented by the CHIRP data, it will be possible to ${ }^{14} \mathrm{C}$-date the lake-level fluctuations reflected in the CHRIP data and 
thereby test the hypothesis that northern hemisphere and southern hemisphere hydroclimate expressions are antiphased on millennial timescales in response to ITCZ forcing.

In addition to significantly advancing the study of millennial and orbital tropical South American hydroclimate variability, the data potentially archived in the sediment column at Tota (e.g., grain size, $\mathrm{C}: \mathrm{N}, \delta^{13} \mathrm{C}, \delta^{15} \mathrm{~N}$, leaf wax $\delta^{2} \mathrm{H}$, pollen, diatoms) would provide significant opportunities to investigate sub-millennial to decadal climate variability during the late Quaternary. These data would provide additional context for interpreting the long-term stadial/interstadial lake-level variations at Tota, as well as higher-frequency variability during other prominent climate events through the late Glacial and Holocene (e.g., Younger Dryas, the middle Holocene arid interval, the Medieval Climate Anomaly, and Little Ice Age).

Geophysical examinations of Andean lakes are rare, and few South American hydroclimate reconstructions extend beyond the Holocene - and those that do are predominantly from southern hemisphere study sites. Our geophysical results from the upper $20 \mathrm{~m}$ of the sedimentary archive of Tota represent up to 60,000 years of northern hemisphere Andean hydroclimate history and provide much needed data regarding the climate dynamics of northern hemisphere South America during the MIS 4/MIS 3 transition, MIS 2 and the LGM, and through MIS 1. However, a deeper-penetrating airgun-sourced seismic reflection survey conducted at the same time has indicated that the sedimentary archive at Tota exceeds $300 \mathrm{~m}$ (Fig. 7). Therefore, while the geophysical data presented in this study reflect the hydroclimate history at Tota across glacial/interglacial and stadial/interstadial boundaries, it should be viewed as a part of a larger effort that has the potential to develop a paleoclimate record of the northern hemisphere Andes that spans the last $\sim 1$ million years (Soreghan and Cohen 2013; Bird et al. 2015). Because of the ephemeral nature of lakes along geologic time-scales, lacustrine records that span such a length 
of time are exceptionally rare. There is no indication that Tota has ever completely dried during its long lifespan, so future efforts at this study site may eventually provide one of the longest continuous lacustrine-sourced paleoclimate records produced from South America.

\section{Conclusions}

Geophysical evidence for significant lake-level fluctuations during the late Quaternary at Lago de Tota on orbital and millennial timescales suggest that the lake volume of Tota is sensitive to the impacts of climatic changes on the regional long-term P/E balance. Based on the timing and magnitude of lake-level changes at Tota and other South American lakes, we propose that over these timescales the mean position of the ITCZ imparts the greatest influence on regional precipitation. The geophysical data support a subdued monsoon and generally low lake-levels at Tota during the end of MIS 4 due to a southerly mean latitude of the ITCZ in response to a disproportionately cool northern hemisphere. Following MIS 4, a northern shift in ITCZ latitude resulted as global temperatures warmed through MIS 3, increasing precipitation delivery to the Northern Hemisphere and resulting in rising lake-levels at Tota. The ITCZ returned to a southerly latitude as Northern Hemisphere ice sheets expanded during MIS 2 and the LGM, driving lake-levels at Tota to their lowest point in our recorded data. Lake-levels rose steadily post-LGM, with the exception of a brief, but significant, reduction during H1. After H1, through MIS 1 and the Holocene, a northern migration of the ITCZ increased Northern Hemisphere precipitation delivery and caused lake-levels to rise to their current level.

Due to the exceptionally thick sedimentary archive at Tota, future work has the potential to develop a paleoclimate record that spans more than one million years. Lake-based 
paleoclimate reconstructions over timescales of such length are rare, but essential for investigating climate sensitivities to global climate boundary conditions - especially during glacial/interglacial and stadial/interstadial transitions as well as across major climatic boundaries, like the Mid-Pleistocene Transition.

\section{Acknowledgments}

This research was partially supported by grants from the US National Science Foundation (EAR 1445649) and Indiana University-Purdue University, Indianapolis, IN (RSFG \& IDF). Partial support was also provided by the Inter-American Institute for Global Change Research (IAI) CRN3038, which is supported by the US National Science Foundation (Grant GEO-1128040).

\section{References}

Anselmetti FS, Ariztegui D, Hodell DA, Hillesheim M, Brenner M, Gilli A, McKenzie J, Mueller A. (2006) Late Quaternary climate-induced lake level variations in Lake Petén Itzá, Guatemala, inferred from seismic stratigraphic analysis. Palaeogeogr Palaeoclimatol Palaeoecol. 230:52-69.

Baker PA, Rigsby CA, Seltzer GO, Fritz SC, Lowenstein TK, Bacher NP, Veliz C. (2001a) Tropical climate changes at millennial and orbital timescales on the Bolivian Altiplano. Nature 409:698.

Baker PA, Seltzer GO, Fritz SC, Dunbar RB, Grove MJ, Tapia PM, Cross SL, Rowe HD, Broda JP. (2001b) The history of South American tropical precipitation for the past 25,000 years. Science 291:640-643. 
Bird B, Wattrus N, Fonseca H, Velasco F, Escobar J. (2015) Assessing the deep drilling potential of Lago de Tota, Colombia, with a seismic survey. AGU Fall Meeting Abstracts.

Bintanja R, van de Wal R, Oerlemans J. (2005) Modelled atmospheric temperatures and global sea levels over the past million years. Nature. 437.

Bogota-a R, Groot M, Hooghiemstra H, Lourens L, Van der Linden M, Berrio J. (2011) Rapid climate change from north Andean Lake Fúquene pollen records driven by obliquity: implications for a basin-wide biostratigraphic zonation for the last $284 \mathrm{ka}$. Quat Sci Rev. $30: 3321-3337$.

Broccoli AJ, Dahl KA, Stouffer RJ. (2006) Response of the ITCZ to Northern Hemisphere cooling. Geophys Res Lett. 33.

Cañón Barriga JE, Valdes J. (2011) Assessing the influence of global climate and anthropogenic activities on the water balance of an Andean Lake. J Water Res Protect. 3:883-891.

Chiang JC, Bitz CM. (2005) Influence of high latitude ice cover on the marine Intertropical Convergence Zone. Clim Dynam. 25:477-496.

Cruz FW, Vuille M, Burns SJ, Wang X, Cheng H, Werner M, Edwards RL, Karmann I, Auler AS, Nguyen H. (2009) Orbitally driven east-west antiphasing of South American precipitation. Nat Geosci 2:210.

Cruz Jr FW, Burns SJ, Jercinovic M, Karmann I, Sharp WD, Vuille M. (2007) Evidence of rainfall variations in Southern Brazil from trace element ratios $(\mathrm{Mg} / \mathrm{Ca}$ and $\mathrm{Sr} / \mathrm{Ca})$ in a Late Pleistocene stalagmite. Geochim Cosmochim Ac. 71:2250-2263.

Cruz Jr FW, Karmann I, Viana Jr O, Burns SJ, Ferrari JA, Vuille M, Sial AN, Moreira MZ. (2005) Stable isotope study of cave percolation waters in subtropical Brazil: implications for paleoclimate inferences from speleothems. Chem Geo. 220:245-262. 
Eidt RC. (1968) Some comments on the geomorphology of highland basins in the Cordillera Oriental of Colombia. Rev Geog:141-156.

Escobar J, Hodell DA, Brenner M, Curtis JH, Gilli A, Mueller AD, Anselmetti FS, Ariztegui D, Grzesik DA, Pérez L. (2012) A 43-ka record of paleoenvironmental change in the Central American lowlands inferred from stable isotopes of lacustrine ostracods. Quat Sci Rev. 37:92-104.

Flantua S, Hooghiemstra H, Vuille M, Behling H, Carson JF, Gosling W, Hoyos I, Ledru M-P, Montoya E, Mayle F. (2016) Climate variability and human impact in South America during the last 2000 years: synthesis and perspectives from pollen records. Clim Past. 12:483-523.

Fonseca H, Reyes Í. (2016) Tota Lake. Landscapes and Landforms of Colombia. Springer, pp. 99-106.

Fritz SC, Baker PA, Lowenstein TK, Seltzer GO, Rigsby CA, Dwyer GS, Tapia PM, Arnold KK, Ku T-L, Luo S. (2004) Hydrologic variation during the last 170,000 years in the southern hemisphere tropics of South America. Quaternary Res. 61:95-104.

Garreaud RD, Vuille M, Compagnucci R, Marengo J. (2009) Present-day South American climate. Palaeogeogr Palaeoclimatol Palaeoecol. 281:180-195.

Gelbrecht M, Boers N, Kurths J. (2017) A complex network representation of wind flows. Chaos. 27:035808.

Grimm AM. (2003) The El Niño impact on the summer monsoon in Brazil: regional processes versus remote influences. J Climate. 16:263-280.

Hamilton EL. (1979) Sound velocity gradients in marine sediments. J Acoust Soc Am. 65:909. 
Haug GH, Hughen KA, Sigman DM, Peterson LC, Röhl U. (2001) Southward migration of the intertropical convergence zone through the Holocene. Science. 293:1304-1308.

Hemming S. (2004) Heinrich events: Massive late Pleistocene detritus layers of the North Atlantic and their global climate imprint. Rev Geophys. 42:1.

Hodell DA, Anselmetti FS, Ariztegui D, Brenner M, Curtis JH, Gilli A, Grzesik DA, Guilderson TJ, Müller AD, Bush MB. (2008) An 85-ka record of climate change in lowland Central America. Quat Sci Rev. 27:1152-1165.

Ivanochko TS, Ganeshram RS, Brummer G-JA, Ganssen G, Jung SJ, Moreton SG, Kroon D. (2005) Variations in tropical convection as an amplifier of global climate change at the millennial scale. Earth Planet Sci Lett. 235:302-314.

Liu D, Wang Y, Cheng H, Edwards RL, Kong X, Wang X, Hardt B, Wu J, Chen S, Jiang X. (2010) Sub-millennial variability of Asian monsoon intensity during the early MIS 3 and its analogue to the ice age terminations. Quat Sci Rev. 29:1107-1115.

Mantua N, Hare S. (2002) The Pacific decadal oscillation. J. Oceanog. 58:35-44.

McGee D, Donohoe A, Marshall J, Ferreira D. (2014) Changes in ITCZ location and crossequatorial heat transport at the Last Glacial Maximum, Heinrich Stadial 1, and the midHolocene. Earth Planet Sci Lett. 390:69-79.

Mollier-Vogel E, Leduc G, Böschen T, Martinez P, Schneider RR. (2013) Rainfall response to orbital and millennial forcing in northern Peru over the last 18 ka. Quat Sci Rev. 76:2938.

Mosblech NA, Bush MB, Gosling WD, Hodell D, Thomas L, Van Calsteren P, Correa-Metrio A, Valencia BG, Curtis J, Van Woesik R. (2012) North Atlantic forcing of Amazonian precipitation during the last ice age. Nat Geosci. 5:817. 
Mueller AD, Anselmetti FS, Ariztegui D, Brenner M, Hodell DA, Curtis JH, Escobar J, Gilli A, Grzesik DA, Guilderson TP. (2010) Late Quaternary palaeoenvironment of northern Guatemala: evidence from deep drill cores and seismic stratigraphy of Lake Petén Itzá. Sedimentology 57:1220-1245.

NGRIP Members, 2004. High resolution Climate Record of the Northern Hemisphere reaching into the last Glacial Interglacial Period. Nature. 431:147-151.

Pahnke K, Sachs JP, Keigwin L, Timmermann A, Xie SP. (2007) Eastern tropical Pacific hydrologic changes during the past 27,000 years from $\mathrm{D} / \mathrm{H}$ ratios in alkenones. Paleoceanography 22.

Peterson LC, Haug GH, Hughen K, Rohl U. (2000) Rapid changes in the hydrologic cycle of the tropical Atlantic during the last glacial. Science. 290:1947-1951.

Poveda G, Álvarez DM, Rueda OA. (2011) Hydro-climatic variability over the Andes of Colombia associated with ENSO: a review of climatic processes and their impact on one of the Earth's most important biodiversity hotspots. Clim Dynam. 36:2233-2249.

Poveda G, Mesa OJ. (1997) Feedbacks between hydrological processes in tropical South America and large-scale ocean-atmospheric phenomena. J Climate. 10:2690-2702.

Remier PJ, Brown TA, Remier RW. (2004) Discussion: Reporting and calibration of post-bomb 14C data. Radiocarbon. 46:1299-1304.

Rowan D, Kalff J, Rasmussen J. (1992) Estimating the mud deposition boundary depth in lakes from wave theory. Canadian J Fish Aquat Sci. 49:2490-2497.

Schneider T, Bischoff T, Haug GH. (2014) Migrations and dynamics of the intertropical convergence zone. Nature 513:45. 
Stansell ND, Abbott MB, Rull V, Rodbell DT, Bezada M, Montoya E. (2010) Abrupt Younger Dryas cooling in the northern tropics recorded in lake sediments from the Venezuelan Andes. Earth Planet Sci Lett. 293:154-163.

Soreghan, G. S., and A. S. Cohen. "Scientific drilling and the evolution of the earth system: climate, biota, biogeochemistry and extreme systems." Scientific Drilling 16 (2013): 6372.

Stuvier M, Remier P. (1993) Extended ${ }^{14} \mathrm{C}$ data base and revised CALIB 3.0. ${ }^{14} \mathrm{C}$ age calibration. Radiocarbon. 35:1.

United States Geological Survey, Earth Resources Observation and Science Center. (2017) Earth explorer 3 arc second SRTM elevation data.

van der Hammen T. (1974) The Pleistocene changes of vegetation and climate in tropical South America. J Biogeogr. 3-26.

Van Der Hammen T, Hooghiemstra H. (2000) Neogene and Quaternary history of vegetation, climate, and plant diversity in Amazonia. Quat Sci Rev. 19:725-742.

Vandergoes MJ, Newnham RM, Preusser F, Hendy CH, Lowell TV, Fitzsimons SJ, Hogg AG, Kasper HU, Schlüchter C. (2005) Regional insolation forcing of late Quaternary climate change in the Southern Hemisphere. Nature 436:242.

Viviroli D, Dürr HH, Messerli B, Meybeck M, Weingartner R. (2007) Mountains of the world, water towers for humanity: Typology, mapping, and global significance. Water resour res. 43.

Vuille M, Werner M. (2005) Stable isotopes in precipitation recording South American summer monsoon and ENSO variability: observations and model results. Clim Dynam 25:401413. 
Wang X, Auler AS, Edwards R, Cheng H, Ito E, Wang Y, Kong X, Solheid M. (2007)

Millennial-scale precipitation changes in southern Brazil over the past 90,000 years.

Geophys Res Lett. 34.

Wang X, Auler AS, Edwards RL, Cheng H, Ito E, Solheid M. (2006) Interhemispheric antiphasing of rainfall during the last glacial period. Quat Sci Rev. 25:3391-3403.

Yokoyama Y, De Deckker P, Lambeck K, Johnston P, Fifield LK. (2001) Sea-level at the Last Glacial Maximum: evidence from northwestern Australia to constrain ice volumes for oxygen isotope stage 2. Palaeogeogr Palaeoclimatol Palaeoecol. 165:281-297.

\section{Tables}

Table 1. Down-core radiocarbon dates collected from Lago de Tota.

\begin{tabular}{|c|c|c|c|c|c|c|}
\hline Core & Type of core & $\begin{array}{c}\text { Material } \\
\text { dated }\end{array}$ & $\begin{array}{c}\text { Depth, } \\
\text { cm }\end{array}$ & $\begin{array}{c}\text { Median }{ }^{14} \mathrm{C} \text { cal } \\
\text { yr BP }\end{array}$ & $+/-$ & $\begin{array}{c}\text { Average } \\
\text { sedimentation } \\
\text { rate }\left(\mathrm{cm} \mathrm{yr}^{-1}\right)\end{array}$ \\
\hline H-13 & Surface & $\mathrm{n} / \mathrm{a}$ & 0 & -63 & 0 & $\mathrm{n} / \mathrm{a}$ \\
\hline $\mathrm{H}-13$ & Surface & Charcoal & 19.45 & 600 & 50 & 0.03 \\
\hline $\mathrm{H}-13$ & Surface & Charcoal & 37.5 & 1190 & 70 & 0.03 \\
\hline $\mathrm{I}-13$ & Surface & $\mathrm{n} / \mathrm{a}$ & 0 & -63 & 0 & $\mathrm{n} / \mathrm{a}$ \\
\hline $\mathrm{I}-13$ & Surface & Charcoal & 22 & 700 & 50 & 0.03 \\
\hline $\mathrm{I}-13$ & Surface & Charcoal & 37.5 & 1190 & 20 & 0.03 \\
\hline $\mathrm{J}-13$ & Surface & $\mathrm{n} / \mathrm{a}$ & 0 & -63 & 0 & $\mathrm{n} / \mathrm{a}$ \\
\hline $\mathrm{J}-13$ & Surface & Charcoal & 19 & 430 & 20 & 0.04 \\
\hline $\mathrm{J}-13$ & Surface & Charcoal & 33 & 1380 & 70 & 0.02 \\
\hline D-13 & Livingstone & $\mathrm{n} / \mathrm{a}$ & 0 & -63 & 0 & $\mathrm{n} / \mathrm{a}$ \\
\hline D-13 & Livingstone & Charcoal & 110 & 2594 & 45 & 0.04 \\
\hline D-13 & Livingstone & Charcoal & 280 & 10054 & 30 & 0.03 \\
\hline D-15 & Livingstone & $\mathrm{n} / \mathrm{a}$ & 0 & -65 & 0 & $\mathrm{n} / \mathrm{a}$ \\
\hline D-15 & Livingstone & Charcoal & 96 & 6200 & 60 & 0.02 \\
\hline D-15 & Livingstone & Charcoal & 203 & 8380 & 45 & 0.02 \\
\hline $\mathrm{J}-15$ & Livingstone & $\mathrm{n} / \mathrm{a}$ & 0 & -65 & 0 & $\mathrm{n} / \mathrm{a}$ \\
\hline
\end{tabular}




\begin{tabular}{|lllclll|} 
J-15 & Livingstone & Charcoal & 127 & 3010 & 20 & 0.04 \\
J-15 & Livingstone & Charcoal & 97 & 3140 & 20 & 0.03 \\
J-15 & Livingstone & Charcoal & 200 & 3940 & 80 & 0.05 \\
J-15 & Livingstone & Charcoal & 299 & 9120 & 80 & 0.03 \\
\hline
\end{tabular}

Table 2. The evolution of the lake basin at Tota over the last $\sim 60,000 \mathrm{Ka}$ in terms of lake-level and MDB location, determined through the transgressions and regressions observed in the seismic data. Positive values for " $\triangle \mathrm{MDB}$ " indicate transgressive periods, when the surface area of the lake was expanding during periods of higher lake-levels. Negative values indicate the opposite.

\begin{tabular}{|ccccccc|}
\hline $\begin{array}{c}\text { Seismic } \\
\text { sequence } \\
\text { (SS) }\end{array}$ & $\sim$ Age & Depth & $\begin{array}{c}\text { Thickness } \\
\text { of unit (m) }\end{array}$ & $\begin{array}{c}\text { Thickness of } \\
\text { unit (TWTT, } \\
\text { ms) }\end{array}$ & $\begin{array}{c}\Delta \text { Lake- } \\
\text { level at } \\
\text { SW shore }\end{array}$ & $\Delta$ MDB \\
\hline 1 & $60 \mathrm{ka}$ & $46.5 \mathrm{~m}$ & $\sim 3.9$ & 5 & $\mathrm{~N} / \mathrm{A}$ & $\mathrm{N} / \mathrm{A}$ \\
2 & $59-44 \mathrm{ka}$ & $41.5 \mathrm{~m}$ & 5 & 6.5 & $+4.9 \mathrm{~m}$ & $+45 \mathrm{~m}$ \\
3 & $43-27 \mathrm{ka}$ & $40.5 \mathrm{~m}$ & 1 & 1.3 & $+1.7 \mathrm{~m}$ & $+15 \mathrm{~m}$ \\
4 & $26-25 \mathrm{ka}$ & $39.5 \mathrm{~m}$ & 1 & 1.3 & $-2.8 \mathrm{~m}$ & $-85 \mathrm{~m}$ \\
5 & $24-23 \mathrm{ka}$ & $38.8 \mathrm{~m}$ & 0.7 & 0.9 & $-3 \mathrm{~m}$ & $-105 \mathrm{~m}$ \\
6 & $22-16 \mathrm{ka}$ & $37.8 \mathrm{~m}$ & 1 & 1.3 & $+10.1 \mathrm{~m}$ & $+205 \mathrm{~m}$ \\
7 & $15-13 \mathrm{ka}$ & $35.8 \mathrm{~m}$ & 2 & 2.5 & $-4 \mathrm{~m}$ & $-75 \mathrm{~m}$ \\
8 & $12-10 \mathrm{ka}$ & $33.8 \mathrm{~m}$ & 2 & 2.5 & $+2 \mathrm{~m}$ & $+30 \mathrm{~m}$ \\
9 & $9 \mathrm{ka}-$ & $30.9 \mathrm{~m}$ & 2.9 & 3.7 & $+6 \mathrm{~m}$ & $+80 \mathrm{~m}$ \\
\hline
\end{tabular}

\section{Figure captions}

Fig. 1 Location of Laguna de Tota in relation to other major climate records from tropical and subtropical South America. Other lake records are indicated by circles, speleothem records as squares, and ice cores as diamonds. The Cariaco Basin, a marine climate record referenced in this study, is represented by a triangle. 
Fig. 2 A Bathymetry and watershed topography, in meters above Pacific sea-level (USGS EROS 2017). Sediment cores used for this study are represented by red (long Livingstone cores) and yellow (short surface cores) circles. The town of Aquitania on the eastern shore of Tota is represented by the white square. Outflow during times of extremely high lake-level flows out of the watershed at the point marked by the white arrow.

B The black lines overlying the bathymetric map of Tota indicate the transects covered by the CHIRP seismic survey. Sediment core locations are marked by red and yellow circles. Transects near the southwestern and southeastern shores used for lake-level reconstruction are highlighted in yellow and orange respectively.

Fig. 3 Age model constructed by extrapolating the Holocene sedimentation rate at Tota of $3 \mathrm{~m}$ of accumulation per 1000 years. Fourteen ${ }^{14} \mathrm{C}$ dates collected from the upper $\sim 3 \mathrm{~m}$ of sediment provided firm age control through the Holocene.

Fig. 4 A Interpreted seismic data collected near the southwestern shore and B southeastern shore show that the interpreted seismic sequences are continuous across the lake basin. Differences in elevation between the transects are due to differences in bathymetry and littoral slope.

Fig. 5 A Raw seismic data from the southwestern littoral zone at Tota. B A close-up view of a long Livingstone core taken from near the southwestern transect shows the lithological contrast between the upper two seismic sequences. A radiocarbon date taken from near the transition from dark-colored, organic-rich sediments and lighter, clay-rich sediments suggests that this 
lithology change marks the boundary between the Holocene and Late Glacial periods. C Raw seismic image with traced onlapping reflectors. D Annotated seismic image, separated into the 9 interpreted seismic sequences visible in the CHIRP data.

Fig. 6 A North Greenland Ice Core Project (NGRIP) oxygen-18:oxygen-16 data (Members 2004). B A 35 ka record of relative lake-levels from NH Lake Fúquene $\left(5^{\circ} 28^{\prime} 00^{\prime \prime} \mathrm{N} 73^{\circ} 45^{\prime} 00^{\prime \prime} \mathrm{W}\right)$ (van der Hammen, 1974). C A 57 ka record of MDB transgressions and regressions at NH Lago de Tota $\left(5.5446^{\circ} \mathrm{N}, 72.9283^{\circ} \mathrm{W}\right)$, determined through transgressions and regressions of the MDB reflected in the CHIRP data used for this study. D A 50 ka record of lake sediment gamma radiation from SH Salar de Uyuni $\left(20.1338^{\circ} \mathrm{S}, 67.4891^{\circ} \mathrm{W}\right)$, used as a proxy for lake-level (Baker et al, 2001a). E A 32 ka record of \%benthic diatom species from SH Lake Titicaca $\left(15.9254^{\circ} \mathrm{S}, 69.3354^{\circ} \mathrm{W}\right)$ (Tapia et al, 2003). F A 60 ka record of calcite oxygen-18:oxygen-16 from SH Botuverá Cave (27.2167 $\left.\mathrm{S}, 49.15^{\circ} \mathrm{W}\right)$ in Southeastern Brazil (Wang et al. 2007). Temporal constraints for Heinrich events were obtained from Hemming 2004.

Fig. 7 A Map of seismic transects collected in 2015, with a transect across the deepest section of the modern lake highlighted in blue. B Airgun-sourced seismic data collected across this transect shows the thickness of the sedimentary archive preserved at Tota. Based on an estimated average compressional wave speed of $1550 \mathrm{~m} \mathrm{~s}^{-1}$, the sub-bottom sediments across this transect are likely $>350$ m thick.

\section{Figures}




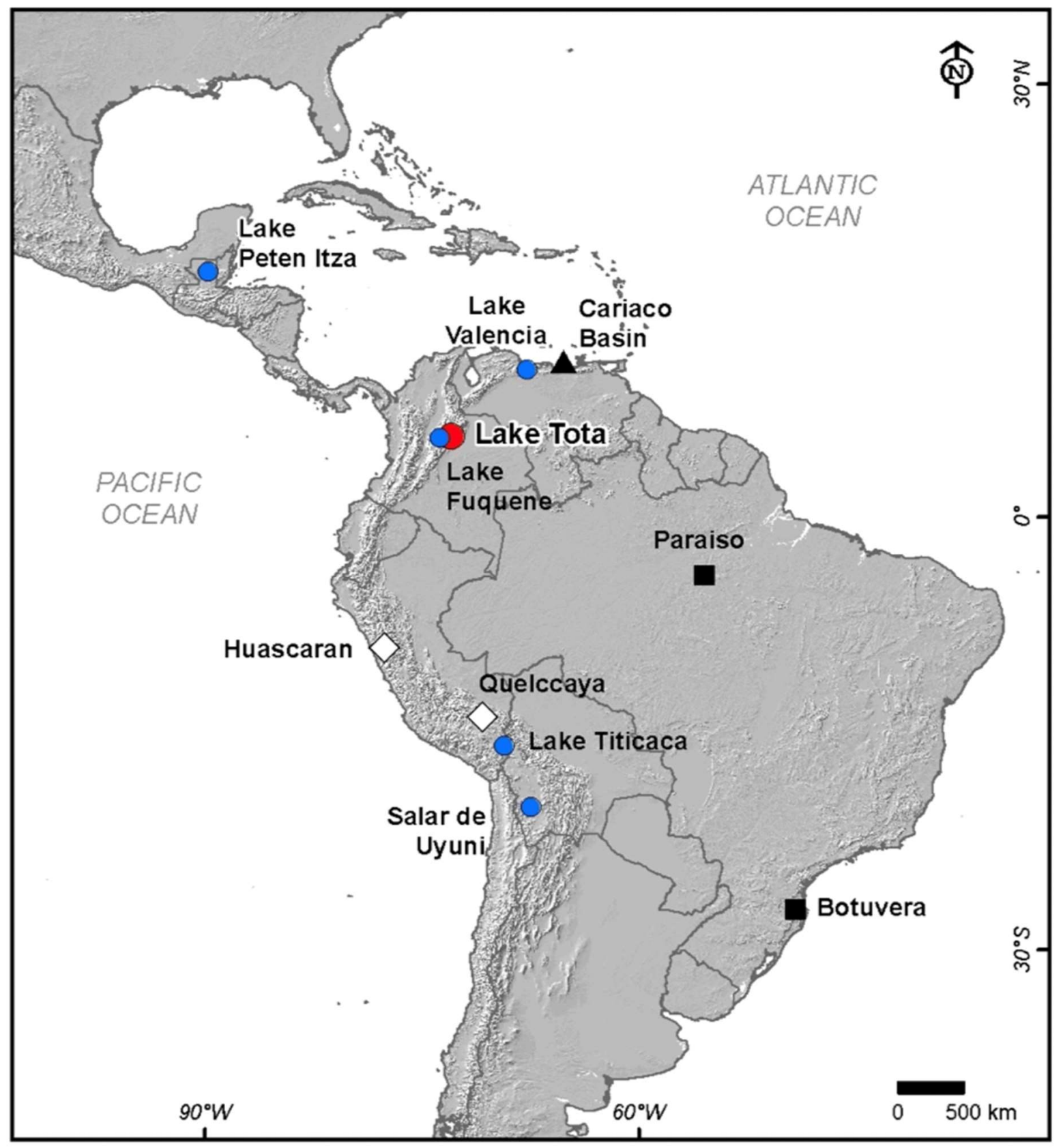



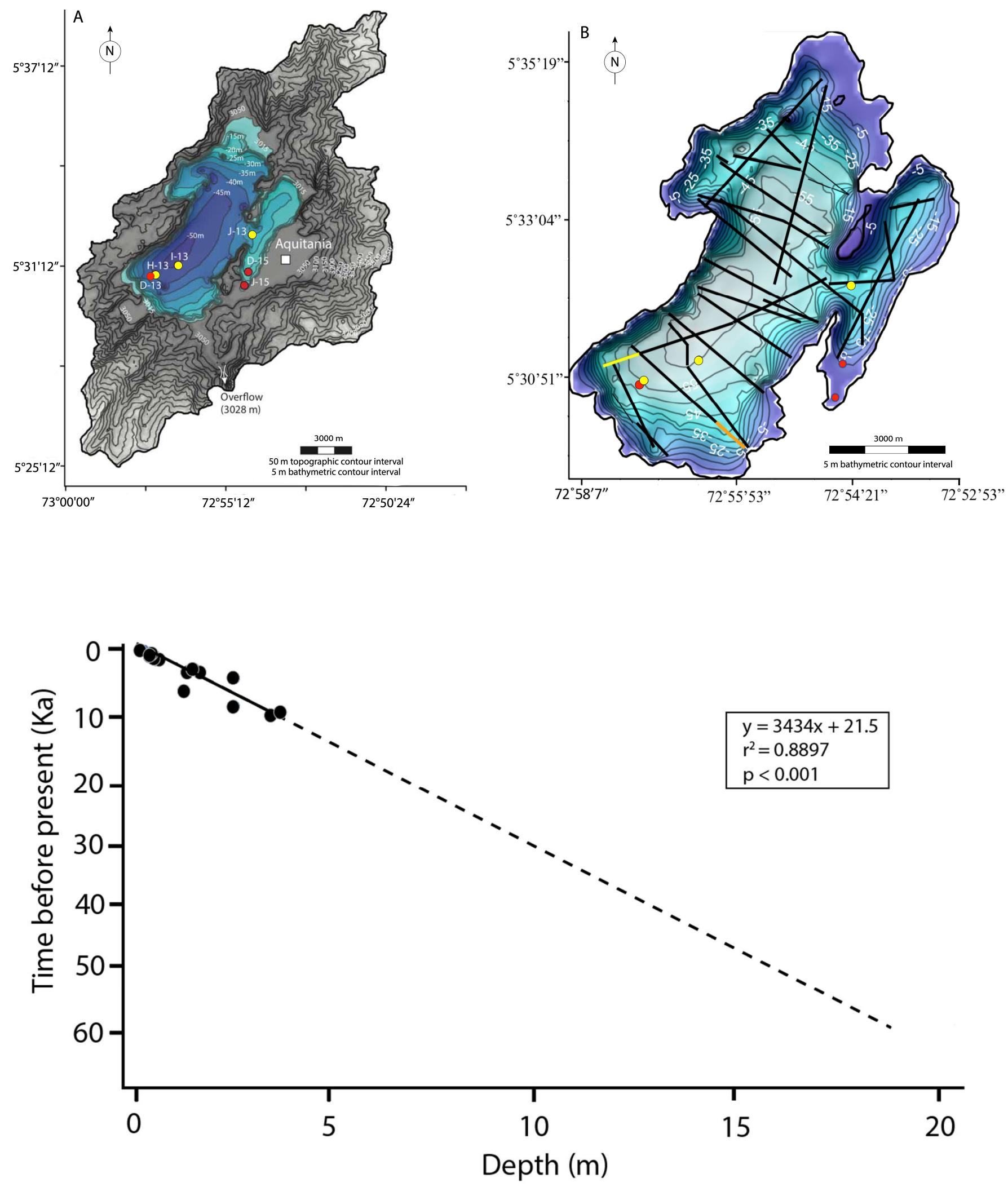

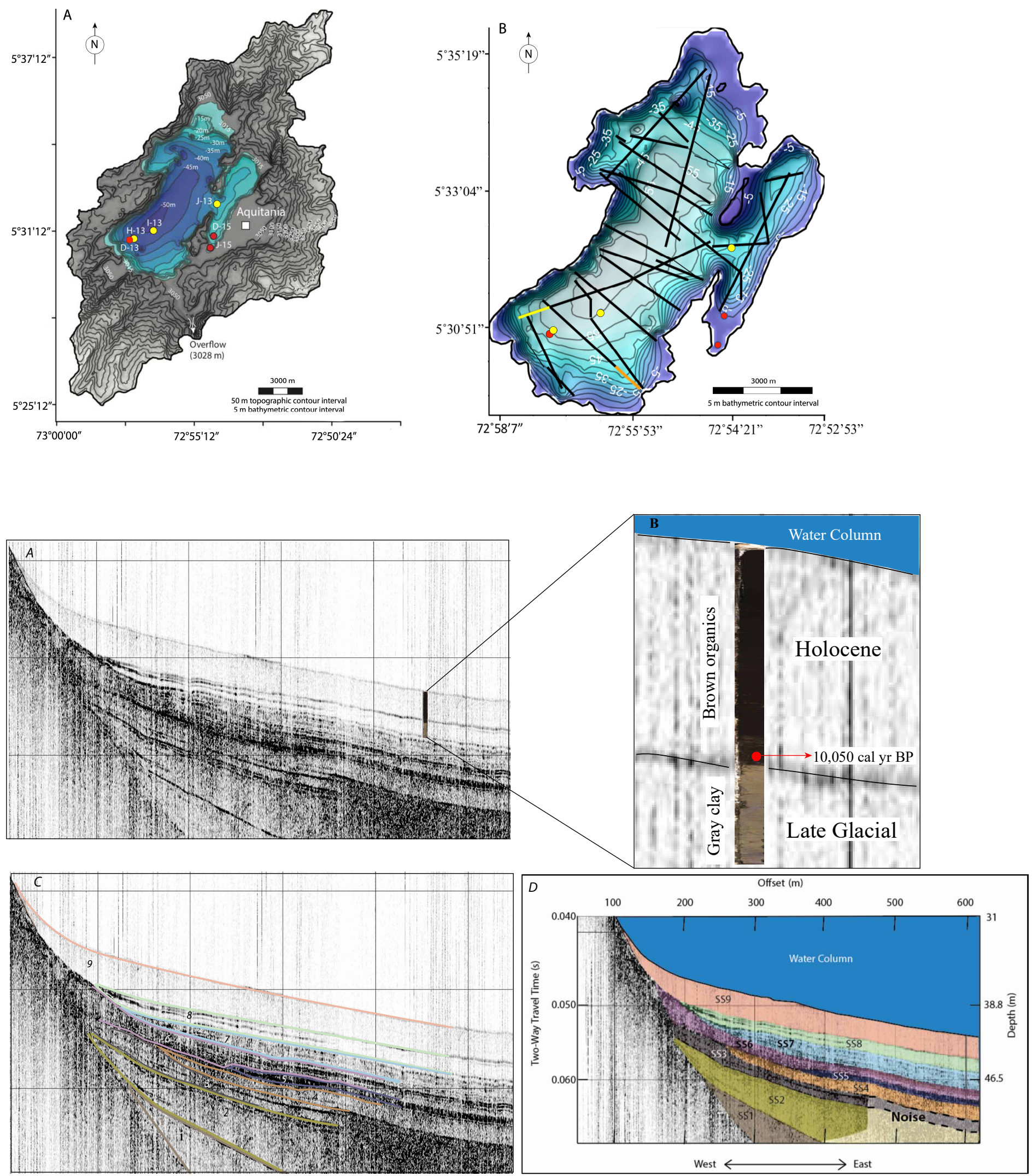


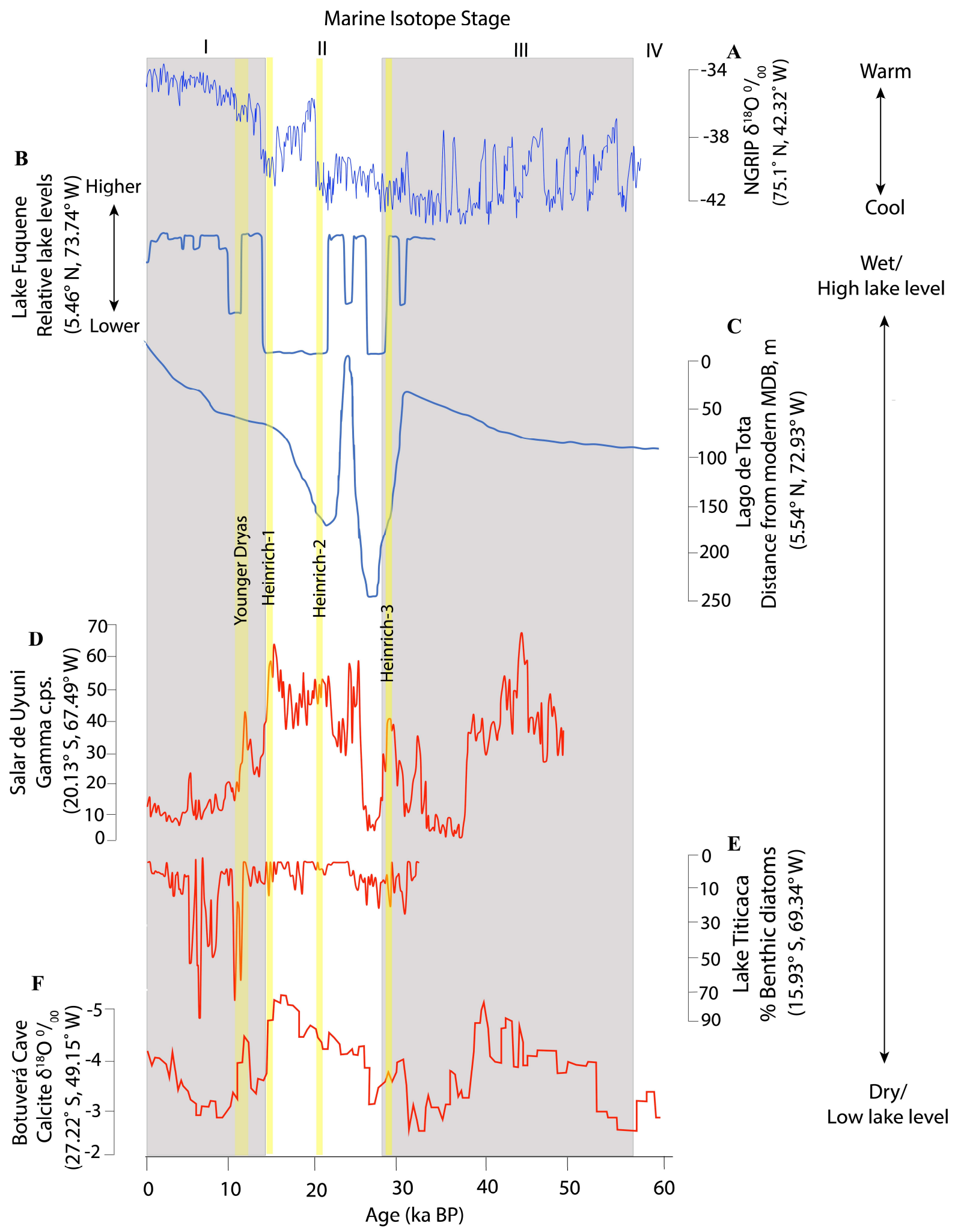



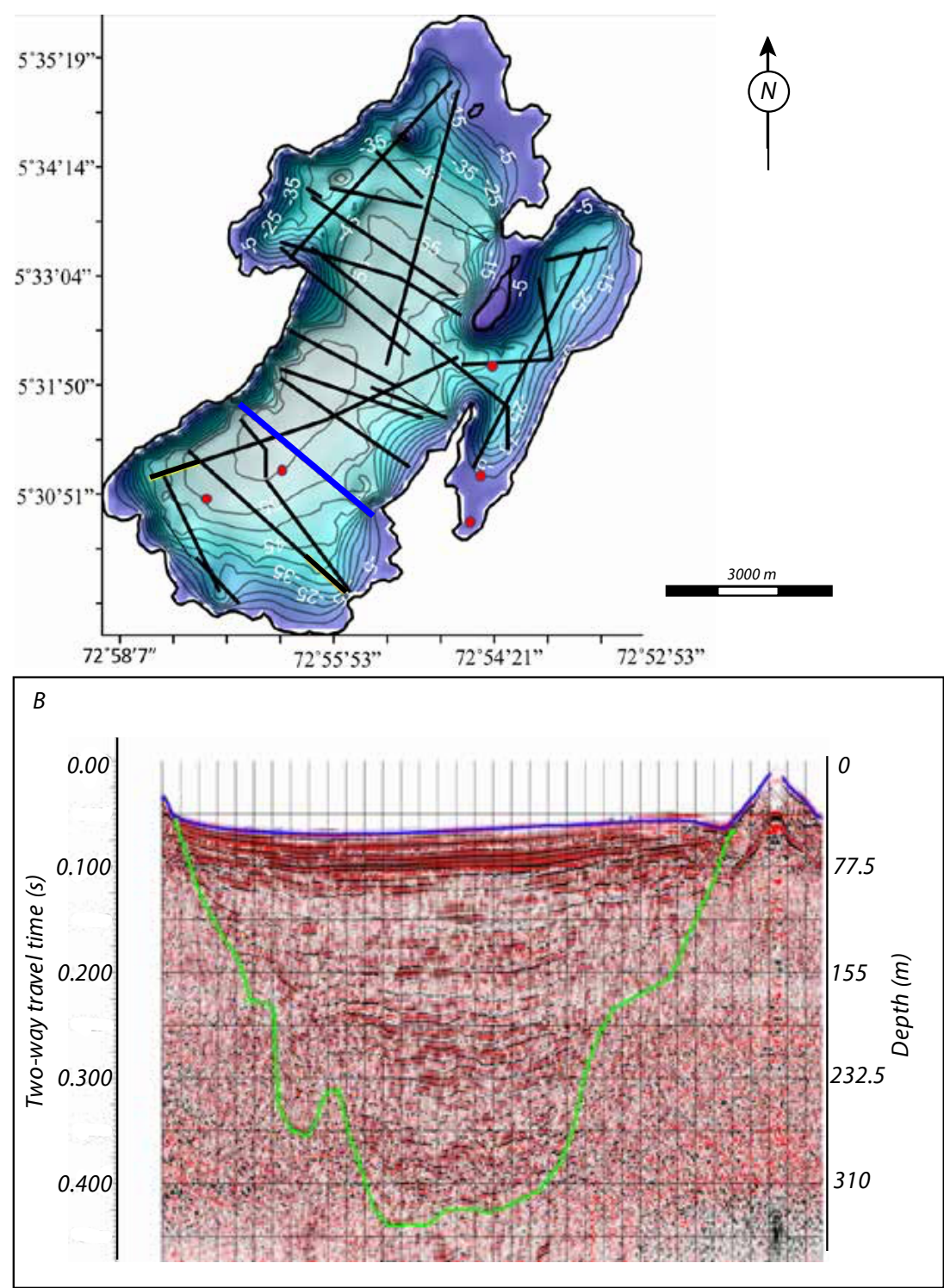